and toil of collecting the various views on what criteria should be used to measure outlet contraction. The opinion of eight authors on this subject is collected and listed in one table, and this is typical of the completeness of the book, as well as illustrating its usefulness.

The publishers must be congratulated on the excellence of their production and the author on his material, and there is no doubt that this first edition will, in due course, be followed by another. Certainly the author has set himself a very high standard for the future.

\section{MODERN TRENDS IN OBSTETRICS AND GYNAECOLOGY \\ (Second Series)}

Edited by KenNeth Bowes, M.D., M.S., M.B., Ch.B., F.R.C.S., F.R.C.O.G. Pp. $x v+407$, with I 76 illustrations. London: Butterworth \& Co. Ltd. 1955. 6os.

The first series of this book contained 50 articles, all of which were useful and practical.

The second series contains 26 articles, on the whole all of a considerably more academic nature. It is a collection of papers, each one of which is admirable in itself, but there is no continuity whatsoever. The book undoubtedly does add to the sum of gynaecological knowledge, but it is sometimes very ' heavy going ' to abstract that knowledge.

The first four articles, which deal with morphology, ontogeny and comparative anatomy of the pelvis with the structure and function of the uterine muscle, with the development of the gonad and primordial germ cells, and similar matters, are completely academic even though authoritative. The topical subject of sex chromatin in cells is lucidly explained. There is a well-informed speculative article on the influence of oestrogens on the formation of uterine tumours and a nice little article by Albert Sharman on ovulation at the menopause.

With the eighth article we start to think about practical human gynaecological matters when Professor Theobald speculates on pain. Then we read an article of great practical value on the metabolic changes associated with operations.

Professor Jeffcoate's assessment of the role of forceps delivery is brilliant and includes very practical illustrations of how to apply Kielland's forceps. P. F. M. Bishop, on premenstrual tension, clarifies modern thought on the subject, which the article on vulval atrophy and leukoplakia does not do, well written as it is. There are other articles on the pathology of anuria and of toxaemia expertly written, as is Ian Donald's work on respiration in the new-born.

It took the reviewer a long time to wade through the book. It is one that should certainly appear in every complete library of gynaecology and it is one well worth borrowing, but it is not one that warrants buying by the average postgraduate student.

E.E.P.

\section{STUDIES ON THE CEREBRAL CORTEX}

By S. Ramon Y CAJAL. Translated by L. M气 Kraft. Pp. xi + I79, with ro8 illustrations London: Lloyd-Luke Ltd. I 955. 27s. 6d.

All those whose work involves a knowledge of the detailed structure of the nervous system will be grateful to Dr. Kraft for this translation of Cajal' classical studies on the Limbic Lobe of the brain Though originally published as long ago as r9ors Cajal's accurate and detailed observations irø material prepared by the Golgi, Nissl and other neurological techniques, still form the basis of oup knowledge of the structure of the limbic lobe, $\overrightarrow{8}$ term first introduced by Broca for the structures surrounding the peduncle as it joins the cerebrad, hemisphere. These include the cingulate gyrug and hippocampus as well as the olfactory bulbe tracts and the olfactory cortex of the tempora lobe. In view of the importance these structures. are now thought to have in 'viscero-somatic' and emotional reactions the republication of Cajal'S work in English is particularly opportune, and will be of great value to all research workers in thi field. It is pleasant also that the appearance of the book should mark the hundredth anniversary of the birth of its author. Dr. Kraft is to be con? gratulated on the very readable and accurate trans $\vec{\tau}$ lation she has produced.

\section{DIFFERENTIAL DIAGNOSIS OF INTERNA DISEASES}

By Julius Bauer, M.D., F.A.C.P. Second edition Pp. xiv +987 , with 66 illustrations. London Grune \& Stratton Inc. I 955. \$ I 5.00.

The British reader, accustomed to the orderly and anonymous style of presentation of works on? differential diagnosis in this country, will find $\mathrm{Dr}$ Bauer's book a striking and possibly refreshing. contrast.

On high-gloss paper and well bound, discussing the differentiation first of leading symptoms and then of leading signs, the approach is formal. The literary style, however, is discursive and at times anecdotal and carries the personality, industry andB enormous practical experience of the author into every page. The contents and index are the only laid-out lists in a book on a subject whose natur almost compels their use. Their omission is a. deliberate attempt to stimulate the intelligences rather than the memory; though admirably moti= vated, in the reviewer's opinion, this feature impairs the value of the book in respect of rapid references and revision.

The author properly deprecates the substitutio of laboratory investigation for clinical examination but devotes more attention to percussion of the heart borders than to assessment of venous pressure by inspection of neck veins. He omits consideration of interatrial septal defects in discussing 
systolic murmurs at the base of the heart. The short section on electro-cardiography is not illustrated.

Throughout the work, constant reference is made to published work and each chapter is followed by a list of up to 300 references. Dr. Bauer's bipartite career has made him familiar with both European and American sources, and the German literature is genertusly represented.

The book demonstrates the author's preoccupation with constitutional factors in the pathogenesis of disease. Although many of the views he presents on this subject are adequately demonstrated and well documented, some of his comments upon the major role of constitutional factors in conditions such as essential hypertension, 'constitutional' diabetes and hyperthyroidism represent his own intelligent reflection rather than scientifically proven fact. The concept of the " constitutional worth of an organ' is frequently used to explain its vulnerability as a site of complication in a general disorder. While this concept seems to have some validity, one would wish it more precisely characterized in physico-chemical terms before using it as extensively as does Dr. Bauer.

In fine it must be said that the book makes pleasant reading; it emanates the author's joy in the intellectual adventures of medicine.

H.K.

\section{ATLAS ZUR SPURENKUNDE DER ELEKTRIZITAT}

\section{(Atlas of the Traces of Electricity)}

By S. Jellinek. Pp. viii +78 , illustrated. Vienna : Springer-Verlag. I 955 .

This unique book has been prepared by an authority on this subject and by an enthusiast at that. Dr. Jellinek is professor at Vienna University, but some of his work was done at Oxford. The manifestations of the electrical current in its impact on living matter and on inanimate objects are briefly described and experiments to reproduce these effects were carried out. All this is illustrated by 199 pictures, many of them in colour.

The figures traced on the skin of men struck by lightning and in such articles as mirrors, branches of trees and conductors show a variety of diffuse or fern-like marks, but occasionally thin lines only develop. Muscle fibres undergo a curious torsion, and this occasionally affects also cell nuclei. The mechanical power of electric current may produce bursts, cuts or perforations. Sometimes a metallic oxide may stain the struck area if it heen near a metal. The patterns of necklaces or even of socks may be traced on the skins, producing tattoo-like marks.

The material of this collection is now displayed in an electro-pathological museum, cared for by the author. There is only one criticism about this book. The description of the pictures is completely divorced from the atlas part of the book and it is difficult to find the key, and a little irritating.

E.N.

\section{PRINCIPLES ANDD PRACTICE OF ANTIBIOTIC THERAPY}

By HeNRY Welch, in collaboration with 16 others. Pp. xix +699 . London: Interscience Publishers Inc. I954. \$12.00.

This large volume is worthy but, unfortunately, very dull. This is partly because it has been written not by one author only but by a team (of which every member happens to be very distinguished) and partly because it seems to be the editorial policy to be fair all round, to draw no comparisons between the different antibiotics, but to state as many facts as possible about all of them.

At times one feels the authors are positively leaning over backwards to avoid making any statement which might lead the reader to prefer one antibiotic to another. How can one reconcile these two paragraphs (occurring on consecutive pages!): 'There seems to be no question now that on rare occasions ... chloramphenicol causes serious blood dyscrasias.' 'It should be emphasized that it cannot be stated with finality that chloramphenicol ... actually caused the blood dyscrasia . . . following (its) use.'

The result, with its enormous number of references, must be very valuable to the pharmacologist, but is not very helpful to the practising clinician (for whom it was evidently intended). Much more practical guidance, for instance, might be given about the relative merits of different preparations of penicillin, and their relative dangers. The advantages of crystalline penicillin given in high dosage two or three times a day, over all longacting preparations, are not made clear (one is led to believe that the maintenance of a steady level of a bactericial drug is still considered an all-important consideration). A book of this sort might well include a separate chapter on the dangers and complications of antibiotic therapy. However, those who wish to consult a complete and up-todate summary of published work on the subject will find this book very helpful.

\section{RADIUM THERAPY: ITS PHYSICAL ASPECTS AND EXTENSIONS WITH RADIOACTIVE ISOTOPES}

By C. W. Wilson, M.Sc., Ph.D., F.Inst.P. Second edition. Pp. ix +286 . London: Baillière, Tindall and Cox Ltd. I956. 37s. 6d.

This book deals with the physical aspects of the local application of radium and radioactive isotopes in the therapy of cancer and is based on the very 